\title{
Behaviour of dolomite, olivine and alumina as primary catalysts in air-steam gasification of sewage sludge
}

\author{
Juan Manuel de Andrés*, Adolfo Narros, María Encarnación Rodríguez \\ Department of Chemical and Environmental Engineering, Universidad Politécnica de Madrid (UPM), c/José Gutiérrez Abascal 2, 28006 Madrid, Spain
}

A R T I C L E I N F O

Keywords:

Primary catalyst

Sewage sludge gasification

Bubbling fluidised bed

Tar content

\begin{abstract}
A B S T R A C T
Sewage sludge gasification assays were performed in an atmospheric fluidised bed reactor using air and air-steam mixtures as the gasifying agents. Dolomite, olivine and alumina are three well known tar removal catalysts used in biomass gasification processing. However, little information is available regarding their performance in sewage sludge gasification. The aim of the current study was to learn about the influence of these three catalysts in the product distribution and tar production during sewage sludge gasification. To this end, a set of assays was performed in which the temperature $\left(750-850^{\circ} \mathrm{C}\right)$, the inbed catalyst content $(0,10$ and $15 \mathrm{wt} \%)$ and the steam-biomass ratio (SB) in the range of $0-1$ were varied with a constant equivalence ratio (ER) of 0.3 . The results were compared to the results from gasification without a catalyst. We show that dolomite has the highest activity in tar elimination, followed by alumina and olivine. In addition to improving tar removal, the presence of water vapour and the catalysts increased the content of $\mathrm{H}_{2}$ in the gases by nearly $60 \%$.
\end{abstract}

\section{Introduction}

Sewage sludge is the liquid or semi-liquid waste generated in wastewater treatment plants [1]. Due to population growth and the strict quality standards required by legislation for wastewater [2], the production of sewage sludge in Europe is continuously increasing.

European legislation restricts many traditional management alternatives for dealing with this waste such as its direct use for cultivation [3] and its disposal in landfills [4]. Additionally, incineration is subject to strong social opposition. For all of these reasons, it is necessary to develop alternative and sustainable disposal routes [5]. Sewage sludge gasification is a potential option. Gasification has the advantages of pathogenic bacteria destruction and volume reduction [6].

Gasification is the thermal process by which the carbonaceous content of sewage sludge is converted to combustible gas and ash in a reducing atmosphere [7]. The gas produced can be burnt in gas engines and turbines to produce energy. It can be used as a raw material in methanol synthesis or in the production of synthetic fuels via the Fischer-Tropsch process [8]. Although gasification can be a self-sufficient process, most of the studies at laboratory or pilot scale have been carried out allothermically (the temperature, air-tobiomass ratio, and steam-to-biomass ratio have been modified independently) [9]. The products, costs and the energetic balance

\footnotetext{
* Corresponding author. Tel.: +34 913363203; fax: +34 913363009

E-mail address: jdeandres@etsii.upm.es (J.M. de Andrés).
}

of the gasification process is highly dependent on the system used [10]. In the case of sewage sludge, an export of heat and/or electricity can be produced when dry sewage sludge is gasified and the product gas is burnt in a gas engine or in a turbine. Nevertheless, if dehydrated sewage sludge is used, it must be dried before gasification and an additional external source of heat could be necessary.

For most applications, the gas must be cleaned to reduce the content of dust and tar [11].

Indeed, as with biomass gasification, one of the major issues in sewage sludge gasification is dealing with the tar that forms [12]. Tar is a complex mixture of condensable hydrocarbons including single and multiple ring aromatic compounds along with other oxygen-containing hydrocarbons and complex polycyclic aromatic hydrocarbons $[13,14]$. These organic impurities can condense in fuel lines and filters in addition to causing problems in the engines and turbines in which the gas is burnt $[15,16]$, principally associated to condensation in compressors and combustion engines inlet devices and to corrosion produced by combustion of the oxygenated compounds of the tars $[17,18]$.

Tar removal technologies can generally be classified as primary (when performed inside the gasifier) or secondary (when performed outside the gasifier). Although the efficiency of secondary methods for tar removal has been extensively demonstrated [11,19-22], major ongoing research is focused on the development of methods for tar removal in economical, efficient and optimised ways [23]. To achieve this goal, primary methods are gaining more attention because they are less complex and expensive than secondary methods. 
If a gasifier is well designed and well operated, the efficiency of tar removal using primary or in-bed catalysts can be as high as that reached with a secondary or downstream reactor [24]. According to Corella and co-workers [24], the similar primary and secondary method efficiencies arise from the fact that, although the gas-catalyst contact is better in a secondary reactor, the tars entering the reactor are more difficult to destroy. On the other hand, it has been reported that tars produced in steam gasification are much easier to eliminate than tars produced during air gasification [20]. Therefore, by optimising the gasification conditions (including the choice of the gasifying agent) and by using primary catalysts as tar removal agents, gas with a low tar content can be obtained while avoiding the need for a second catalytic reactor, irrespective of the necessity of additional gas conditioning systems for removing other unwanted impurities (dust, $\mathrm{NH}_{3}$, etc.). This option would improve the economic feasibility of the gasification process.

Naturally occurring catalysts (principally dolomite and olivine) are the most readily used materials for in-bed catalysts [25-29]. Although some published works have concluded that under similar operating conditions, olivine activity for tar removal is close to dolomite activity [27], results found by other authors [28,29] show that the activity of dolomite is higher. Recently, studies have examined the performance of other kinds of primary catalysts $[12,30,31]$. Alumina and $\mathrm{Ni}$-alumina mixtures have proven to be effective in tar removal and hydrogen production under fluidising conditions.

The current paper deals with the influence of three different primary catalysts - olivine, alumina and dolomite - on sewage sludge gasification and tar production. To this end, analyses of the gas composition, tar production, cold gas efficiency and carbon conversion were carried out for different gasifying agents (air and air-steam mixtures).

\section{Materials and methods}

\subsection{Materials}

The dried sludge samples consisted of spherical aggregates, approximately $2-5 \mathrm{~mm}$ in diameter, that originated from an urban wastewater treatment plant. The elemental analyses of the dried sewage sludge are shown in Table 1 . These data were used to estimate the low heating value (LHV) of the sludge $(11.5 \mathrm{MJ} / \mathrm{kg}$ ) by means of the modified Dulong's formula [10]. Silica sand was used as the bed material. The sludge was crushed and passed through a sieve to obtain particle sizes between 300 and $500 \mu \mathrm{m}$, the same sizes as the three catalysts used. The olivine was supplied by Magnolithe $\mathrm{GmbH}$, Austria, the alumina (Spheralite 505) by Axens Procatalyse Catalysts \& Adsorbents and the dolomite by Dolomite from Norte, Spain.

\subsection{Laboratory scale plant}

Experiments were conducted in the plant shown in Fig. 1. The reactor used was a stainless steel (AISI $316 \mathrm{~L}$ ) fluidised bed reactor with a total height of $700 \mathrm{~mm}$ and an inner diameter of $32 \mathrm{~mm}$. A freeboard with an inner diameter of $46 \mathrm{~mm}$ was located at the top of the reactor. Both the reactor and the freeboard were heated by an electrical furnace.

Inside the gasifier, the bed was held by a distributor plate $(0.1-$ $\mathrm{mm}$ pore size). The gasifying agent entering the reactor was preheated by stainless steel balls placed under the distributor plate. The sludge was fed into the reactor by a dosing system consisting of a hopper and two screw feeders (the dosing and launch screw feeders). The launch screw was inserted into the reactor a few millimetres above the distributor plate by a $12.7-\mathrm{mm}$ outer diameter
Table 1

Elemental analysis of sewage sludge from a wastewater treatment plant (analysis in triplicate).

\begin{tabular}{llrl}
\hline Parameter $^{\text {a }}$ & & Sludge $^{\mathrm{b}}$ & Analytical method \\
\hline Moisture (\%) & & 7.0 & UNE-EN 12880-2001 \\
Organic Mat. (\%) & & 56.0 & UNE-EN 12879-2001 \\
Ash (\%) & 44.0 & UNE-EN 12879-2001 \\
pH & 6.9 & UNE-EN 12176-1998 \\
Total carbon (\%) & & 27.3 & Elementary micro analyser \\
& & & LECO CHNS-932 \\
Nitrogen (\%) & & 4.1 & \\
Hydrogen (\%) & & 4.8 & \\
Sulphur (\%) & & 0.9 & \\
Oxygen (\%) & by difference & 18.9 & \\
Heavy metals & $\mathrm{Cd}$ & 2.7 & UNE-EN 13346-2001 \\
\multicolumn{1}{c}{ (mg/kg) } & & & \\
& $\mathrm{Cu}$ & 402.5 & \\
& $\mathrm{Ni}$ & 58.0 & \\
& $\mathrm{~Pb}$ & 159.5 & \\
& $\mathrm{Zn}$ & 1227.5 & \\
& $\mathrm{Hg}$ & 2.8 & \\
& $\mathrm{Cr}$ & 163.5 & \\
\hline
\end{tabular}

a Dry basis values, except moisture and $\mathrm{pH}$.

b Mean value of three analytical assays.

pipe. The pipe was provided with a water-cooling system used to prevent pyrolysis of the sludge prior to entering the reactor.

The bed height was kept at $100 \mathrm{~mm}$ by a concentric pipe with a 12.7-mm outer diameter, which went through the distributor plate (0.1- $\mathrm{mm}$ pore size) and allowed the overflowing material to collect in a discharge tank.

The airflow rate was regulated by a mass flow controller. With the aid of two rotameters, part of the gasification air was diverted to the screw feeder to help the sludge enter the reactor, while the rest of the air was introduced through the distributor plate. In the air-steam mixture tests, a peristaltic pump was used to introduce water into the reactor at the bottom of the gasifier. The water was preheated by the stainless steel balls placed under the distributor plate.

Downstream of the freeboard, a cyclone and a micronic filter were placed inside a hot box $\left(250^{\circ} \mathrm{C}\right)$ to prevent condensation of the tars. To collect the tars and the water, the gas leaving the hot box was cooled in five condensers containing isopropanol that were placed over an ice bath (following a similar system as was used in the tar protocol, CEN/TS 15439:2006 [32]). Passage through a water filter, a silica gel filter and a cotton filter completed the cleaning of the gases. To measure the tar production, the isopropanol-tar solutions were distilled to eliminate the absorbent liquid (isopropanol). After distillation, the residues (tars) were dried at room temperature until they had a constant weight. Finally, the samples were weighed. The char content was determined according the method used in Ref. [27].

Gas production was measured by a mass flow meter. The dry gas compositions of $\mathrm{N}_{2}, \mathrm{O}_{2}, \mathrm{H}_{2}, \mathrm{CO}, \mathrm{CO}_{2}, \mathrm{CH}_{4}, \mathrm{C}_{2} \mathrm{H}_{6}$ and $\mathrm{C}_{2} \mathrm{H}_{4}$ were determined by means of a micro gas chromatograph (Micro-GC, Varian (P-4900). The time interval between analyses was $5 \mathrm{~min}$.

\subsection{Experimental conditions}

A set of catalysis experiments were carried out to determine the influence of three catalysts - olivine, alumina and dolomite - on the sewage sludge gasification process. The results have been compared with the results in [33], in which tests without catalysts were performed to assess the influence of temperature, the equivalence ratio (ER, defined as the ratio between the flow rate of the air introduced into the reactor and the stoichiometric flow rate of the air required for complete combustion of the sludge) and 


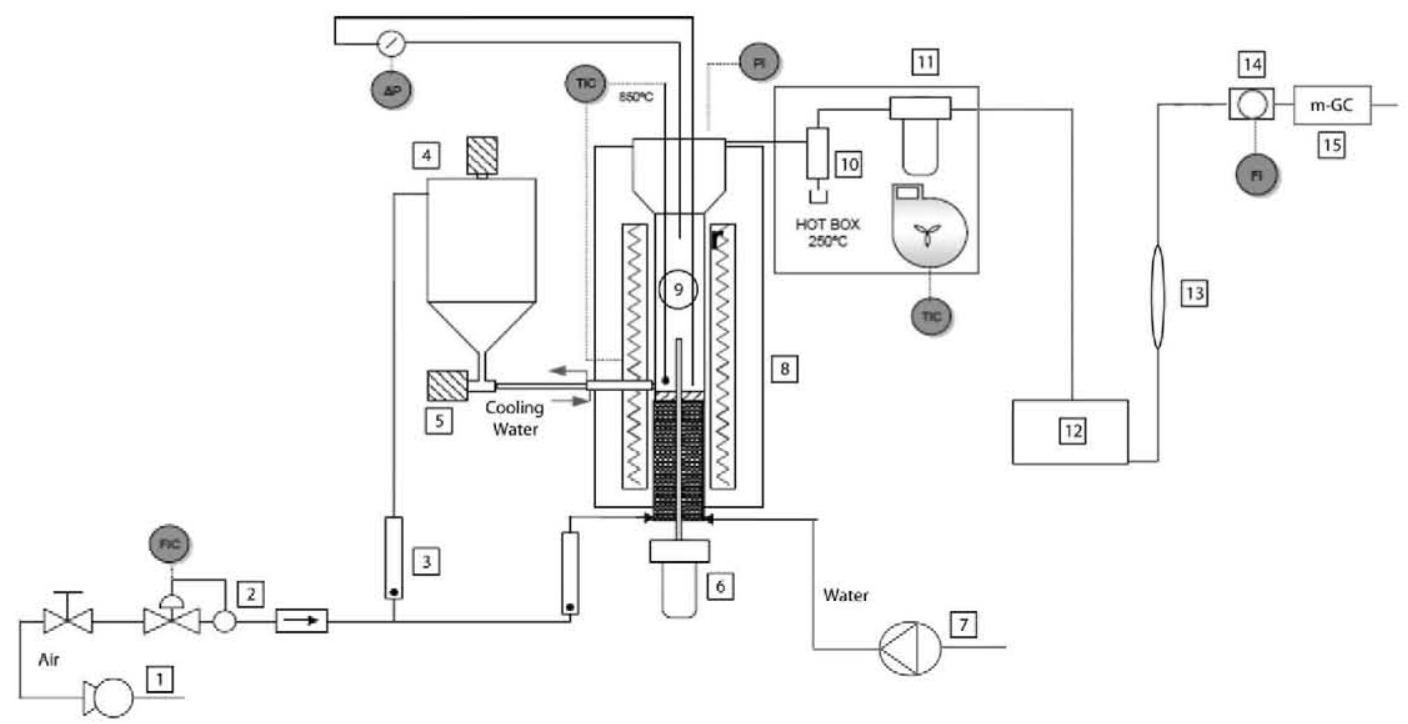

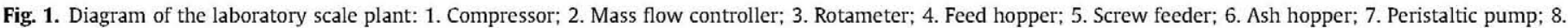
Furnace; 9. Reactor; 10. Cyclone; 11 . Hot filter; 12 . Condensation train; 13 . Water filters, silica gel and cotton; 14. Mass flow meter; 15 . Micro gas-chromatograph.

the steam-biomass ratio (S/B, defined as the flow rate of steam fed to the reactor divided by the flow rate of sludge on a dry and ashfree basis) on the sewage sludge gasification products.

These experiments can be divided into two groups depending on their objective:

- Influence of catalysts: A set of tests was carried out with a constant ER of 0.3 in which the temperature was varied $(750,800$ and $850^{\circ} \mathrm{C}$ ) and different quantities of catalysts (olivine, dolomite and alumina [33]) were added to the gasifier $(0 \%, 10 \%$ and $15 \%$ by weight within the fed sludge).

- Influence of catalyst and steam: Additional tests were performed by adding the catalyst ( $10 \%$ by weight within the fed sludge) at a temperature of $800^{\circ} \mathrm{C}$ with an ER of 0.3 and varying $\mathrm{S} / \mathrm{B}$ ratios $(0,0.5$ and 1$)$.
It was decided to set the ER to 0.3 because, under this condition, tar production was relatively low ( $11 \mathrm{mg} / \mathrm{g} d a f$ ) and the LHV of the gases remained within acceptable levels $\left(4 \mathrm{MJ} / \mathrm{Nm}^{3}\right)$. Tests with catalysts and steam were carried out at $800^{\circ} \mathrm{C}$ because it was found difficult to stabilise the temperature at $850^{\circ} \mathrm{C}$ during steam tests without catalysts [33].

Before each test, a total of $80 \mathrm{~g}$ of silica sand (or sand/catalyst mixture, in catalysed tests) was placed in the gasifier in the appropriate proportions. The conditions and results of these tests are shown in Table 2. Once the temperature of the test was reached, the gasifier was fed with sludge and a specific sand-catalyst mixture ( $20 \%$ of the mass rate of fed sludge). The sand-catalyst proportion of the mixture in each test is shown in Table $2(10-10 \%$ or $5-$ $15 \%$ depending on the test), sand being used to improve fluidization. To avoid the effect of the transition period [34], tests were

Table 2

Results and operating conditions of gasification experiments.

\begin{tabular}{|c|c|c|c|c|c|c|c|c|c|c|c|c|c|c|c|c|c|c|c|c|}
\hline \multirow[b]{2}{*}{ Parameter } & \multirow[b]{2}{*}{ Units } & \multicolumn{19}{|c|}{ Test number } \\
\hline & & 1 & 2 & 3 & 4 & 5 & 6 & 7 & 8 & 9 & 10 & 11 & 12 & 13 & 14 & 15 & 16 & 17 & 18 & 19 \\
\hline Temperature & ${ }^{\circ} \mathrm{C}$ & 750 & 800 & 850 & 750 & 800 & 850 & 750 & 800 & 850 & 750 & 800 & 850 & 750 & 800 & 850 & 800 & 800 & 800 & 800 \\
\hline$u / u_{\mathrm{mf}}$ & & 3.6 & 3.8 & 4 & 3.6 & 3.8 & 4 & 3.6 & 3.8 & 4 & 3.6 & 3.8 & 4 & 3.6 & 3.8 & 4 & 3.8 & 3.8 & 3.8 & 3.8 \\
\hline ER & & 0.3 & 0.3 & 0.3 & 0.3 & 0.3 & 0.3 & 0.3 & 0.3 & 0.3 & 0.3 & 0.3 & 0.3 & 0.3 & 0.3 & 0.3 & 0.3 & 0.3 & 0.3 & 0.3 \\
\hline$S / B$ & & & & & & & & & & & & & & & & & 0.5 & 1.0 & 0.5 & 1.0 \\
\hline Sludge & $\mathrm{g} / \mathrm{min}$ & 1.4 & 1.4 & 1.4 & 1.4 & 1.4 & 1.4 & 1.4 & 1.4 & 1.4 & 1.4 & 1.4 & 1.4 & 1.4 & 1.4 & 1.4 & 1.4 & 1.4 & 1.4 & 1.4 \\
\hline Olivine & $\%$ fed sludge & & & & 10 & 10 & 10 & 15 & 15 & 15 & & & & & & & 10 & 10 & & \\
\hline Dolomite & $\%$ fed sludge & & & & & & & & & & 10 & 10 & 10 & 15 & 15 & 15 & & & 10 & 10 \\
\hline $\begin{array}{l}\text { Sand } \\
\text { Composition }\end{array}$ & $\begin{array}{l}\% \text { fed sludge } \\
\text { dry basis }\end{array}$ & 20 & 20 & 20 & 10 & 10 & 10 & 5 & 5 & 5 & 10 & 10 & 10 & 5 & 5 & 5 & 10 & 10 & 10 & 10 \\
\hline $\mathrm{H}_{2}$ & $\%$ & 7.6 & 10.4 & 12.1 & 8.0 & 11.9 & 13.4 & 9.1 & 11.5 & 13.4 & 10.1 & 13.2 & 13.9 & 9.9 & 12.7 & 15.2 & 13.3 & 14.5 & 15.7 & 16.8 \\
\hline $\mathrm{N}_{2}$ & $\%$ & 65.1 & 60.8 & 57.7 & 64.5 & 58.2 & 57.0 & 63.3 & 59.6 & 57.0 & 62.0 & 57.5 & 55.9 & 63.2 & 59.1 & 53.6 & 56.6 & 55.5 & 54.9 & 54.2 \\
\hline $\mathrm{CH}_{4}$ & $\%$ & 2.7 & 3.0 & 3.3 & 2.6 & 3.4 & 2.8 & 2.8 & 3.0 & 2.8 & 2.9 & 2.9 & 2.8 & 2.8 & 2.7 & 2.9 & 3.2 & 3.0 & 2.9 & 2.7 \\
\hline $\mathrm{CO}$ & $\%$ & 6.9 & 8.0 & 10.1 & 6.5 & 8.4 & 10.3 & 6.7 & 7.5 & 10.2 & 6.9 & 10.2 & 12.7 & 6.1 & 9.0 & 14.4 & 8.3 & 7.8 & 9.1 & 7.5 \\
\hline $\mathrm{CO}_{2}$ & $\%$ & 14.1 & 14.1 & 13.1 & 15.1 & 14.4 & 13.7 & 14.3 & 15.0 & 13.8 & 14.7 & 13.2 & 12.2 & 14.6 & 13.7 & 11.5 & 15.3 & 15.7 & 14.5 & 15.9 \\
\hline $\mathrm{C}_{2} \mathrm{H}_{6}$ & $\%$ & 0.14 & 0.09 & 0.04 & 0.07 & 0.05 & 0.03 & 0.07 & 0.05 & 0.03 & 0.08 & 0.04 & 0.02 & 0.08 & 0.04 & 0.02 & 0.04 & 0.04 & 0.04 & 0.04 \\
\hline $\mathrm{C}_{2} \mathrm{H}_{4}$ & $\%$ & 2.1 & 2.2 & 2.4 & 1.7 & 2.0 & 1.4 & 1.9 & 1.9 & 1.3 & 1.9 & 1.5 & 1.2 & 1.9 & 1.5 & 1.1 & 1.9 & 1.8 & 1.5 & 1.4 \\
\hline LHV gas & $\mathrm{MJ} / \mathrm{Nm}^{3}$ & 2.8 & 3.3 & 3.9 & 2.7 & 3.7 & 3.9 & 3.0 & 3.4 & 3.8 & 3.1 & 3.9 & 4.2 & 2.9 & 3.6 & 4.6 & 3.7 & 3.8 & 4.0 & 3.9 \\
\hline$Y_{\text {gas }}$ & $\mathrm{Nm}^{3} / \mathrm{kg}$ sludge, daf & 2.5 & 2.5 & 2.6 & 2.5 & 2.7 & 2.7 & 2.6 & 2.6 & 2.7 & 2.5 & 2.7 & 2.8 & 2.5 & 2.6 & 2.7 & 2.7 & 2.6 & 2.7 & 2.8 \\
\hline$c_{\text {tar }}$ & $\mathrm{g} / \mathrm{Nm}^{3}$ & 11.8 & 7.6 & 4.3 & 9.8 & 5.1 & 2.8 & 9.6 & 5.0 & 2.0 & 7.0 & 3.6 & 1.9 & 5.6 & 2.4 & 1.0 & 4.6 & 4.4 & 2.7 & 2.5 \\
\hline$Y_{\text {tar }}$ & mg/g sludge, daf & 29.0 & 19.2 & 11.2 & 24.9 & 13.6 & 7.6 & 24.7 & 13.1 & 5.6 & 17.6 & 9.8 & 5.4 & 14.3 & 6.3 & 2.8 & 12.2 & 11.7 & 7.3 & 7.1 \\
\hline GMB & $\%$ & 98.9 & 96.9 & 96.9 & 101.5 & 101.6 & 100.0 & 101.7 & 100.8 & 101.3 & 101.5 & 100.8 & 101.3 & 100.1 & 99.8 & 98.3 & 99.0 & 98.4 & 97.1 & 95.2 \\
\hline$X_{\mathrm{c}}$ & $\%$ & 66.2 & 71.3 & 77.9 & 71.5 & 81.6 & 82.6 & 71.9 & 78.4 & 83.6 & 72.5 & 81.1 & 86.3 & 69.9 & 76.9 & 88.6 & 82.6 & 80.8 & 82.5 & 83.0 \\
\hline$X_{H 2 O}$ & $\%$ & & & & & & & & & & & & & & & & 12.6 & 16.1 & 21.0 & 24.0 \\
\hline GE & $\%$ & 30.4 & 37.4 & 45.5 & 31.1 & 44.6 & 47.3 & 34.6 & 40.6 & 47.8 & 35.9 & 47.3 & 52.6 & 33.9 & 42.7 & 57.3 & 45.2 & 45.0 & 49.4 & 48.6 \\
\hline Char & $\mathrm{g} / \mathrm{kg}$ daf & 88.3 & 56.0 & 37.4 & 36.4 & 34.7 & 14.9 & 61.2 & 36.4 & 16.5 & 59.6 & 38.1 & 13.2 & 76.1 & 41.4 & 11.6 & 31.4 & 43.0 & 31.4 & 34.7 \\
\hline
\end{tabular}


run over $30 \mathrm{~min}$ to reach stable conditions, and then, the tests were continued for $50 \mathrm{~min}$.

To validate each test, a experiment closure mass balance of nearly $100 \%$ was estimated, taking into account the air, water, catalyst and sludge introduced and the products obtained. If the closure balance was less than $95 \%$ or more than $105 \%$ the experiment was not validated.

\section{Results and discussion}

\subsection{Influence of catalysts in the bed}

Figs. 2 and 3 show the gas composition as a function of temperature and amount of catalyst in the bed (olivine and dolomite, respectively) at an ER of 0.3 .
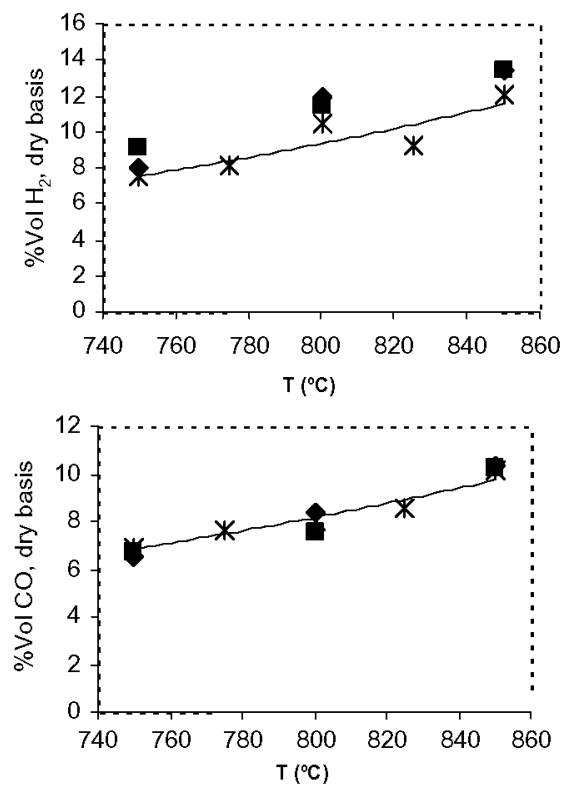

As can be seen in Fig. 2, olivine has a slight influence on the gas composition, although different trends can be observed. The presence of olivine in the bed favours the production of $\mathrm{H}_{2}$, but no significant differences are found when the percentage of olivine added to the gasifier is changed.

The $\mathrm{CH}_{4}, \mathrm{CO}$ and $\mathrm{CO}_{2}$ contents are very similar to those obtained in the tests without catalysts. The variations found in the gas composition suggest that olivine influences the watergas shift, cracking and $\mathrm{CO}_{2}$ and steam reforming reactions, which is in agreement with [35]. Although it is not shown in Fig. 2, the observed decrease in the $\mathrm{C}_{n} \mathrm{H}_{m}$ content reinforces this conclusion.

The final gas composition is a function of the prevalence of one or more simultaneous and competing reactions. Reforming reactions generate $\mathrm{H}_{2}$ and $\mathrm{CO}$ and consume $\mathrm{H}_{2} \mathrm{O}$ and $\mathrm{CO}_{2}\left(\mathrm{CO}_{2}\right.$
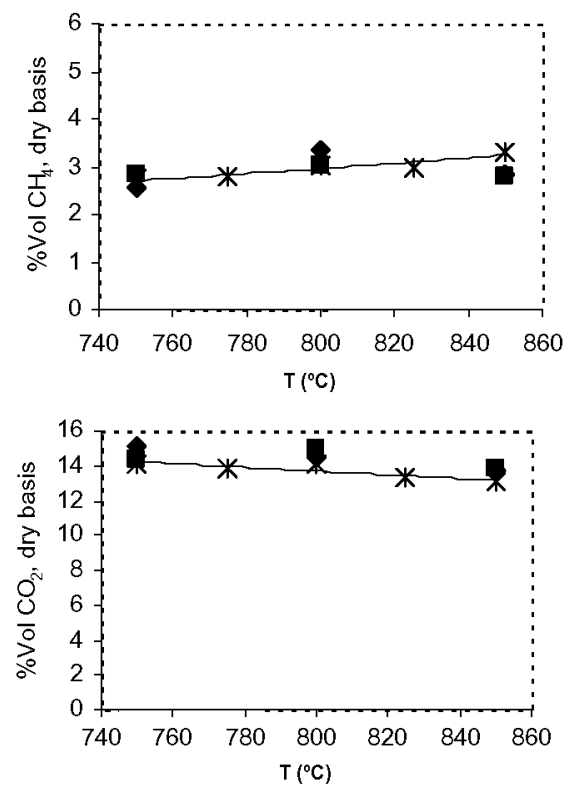

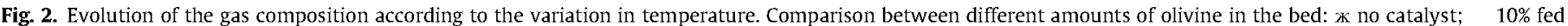
sludge; $15 \%$ fed sludge.
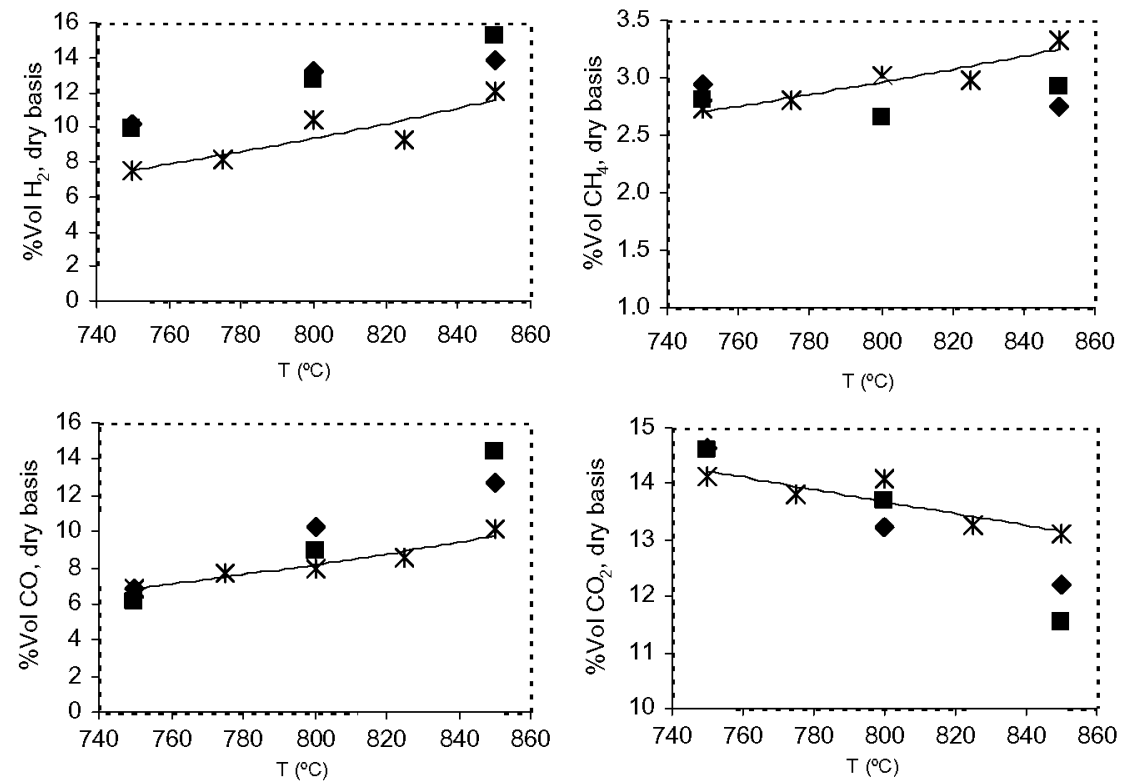


sludge; $15 \%$ fed sludge. 
reforming reactions). However, $\mathrm{CO}_{2}$ and $\mathrm{H}_{2}$ can also be produced from $\mathrm{CO}$ and $\mathrm{H}_{2} \mathrm{O}$ via the water-gas shift reaction.

As occurred with olivine, the presence of dolomite in the bed increases the content of $\mathrm{H}_{2}$ in the produced gas (Fig. 3). Regarding the other gases that were analysed, the production of $\mathrm{CO}$ increased in tests with dolomite, whereas the production of $\mathrm{CH}_{4}, \mathrm{CO}_{2}$ and $\mathrm{C}_{n} \mathrm{H}_{m}$ decreased. These results can be explained by the prevalence of cracking and $\mathrm{CO}_{2}$ reforming reactions, which arises from the limits placed on the water-gas shift and steam reforming reactions by the presence of a small amount of steam in the tests with air. The behaviour of alumina was similar to that of dolomite [33].

Fig. 4 shows the variations in tar concentration for different amounts of catalyst in the bed at $850^{\circ} \mathrm{C}$ and an ER of 0.3 . The tar content decreases with the use of catalysts in the gasifier due to cracking of tars and the steam and $\mathrm{CO}_{2}$ reforming reactions. Additional reductions are achieved by increasing the amount of catalyst added to the bed. Olivine affects the reductions the least, while dolomite is the most active catalyst in tar removal. These results are in agreement with other studies $[28,29]$.

In the presence of olivine, the tar reduction relative to that obtained without a catalyst varied from $14 \%$ (at $750{ }^{\circ} \mathrm{C}$ with $10 \%$ catalyst) to $50 \%$ (at $850^{\circ} \mathrm{C}$ with $15 \%$ catalyst). These results are in agreement with those found by [12]. Under similar conditions, tar reduction varied from $37 \%$ to $65 \%$ with alumina [33] and from



Fig. 4. Tar production for different amounts of catalyst in the bed. $T=850^{\circ} \mathrm{C}$ $\mathrm{ER}=0.3 . Y_{\text {tar }}$ relative (\%) represents the relation between tar production in tests with different amounts of catalyst in the bed and tar production in test with no catalyst (the last representing $100 \%$ ).

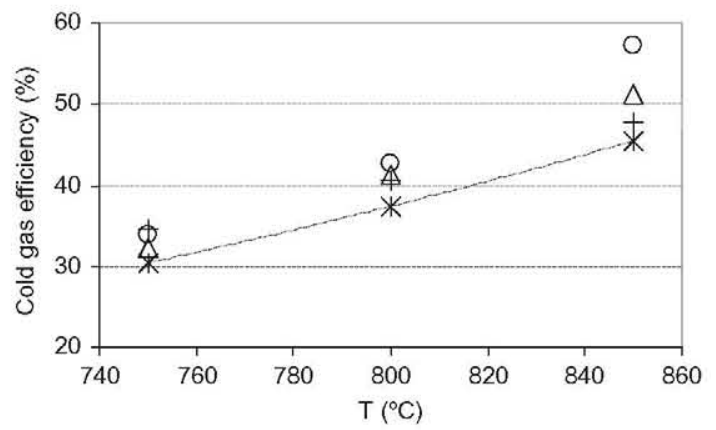

$39 \%$ to $75 \%$ with dolomite. In all cases, tar reduction increased with increasing temperature.
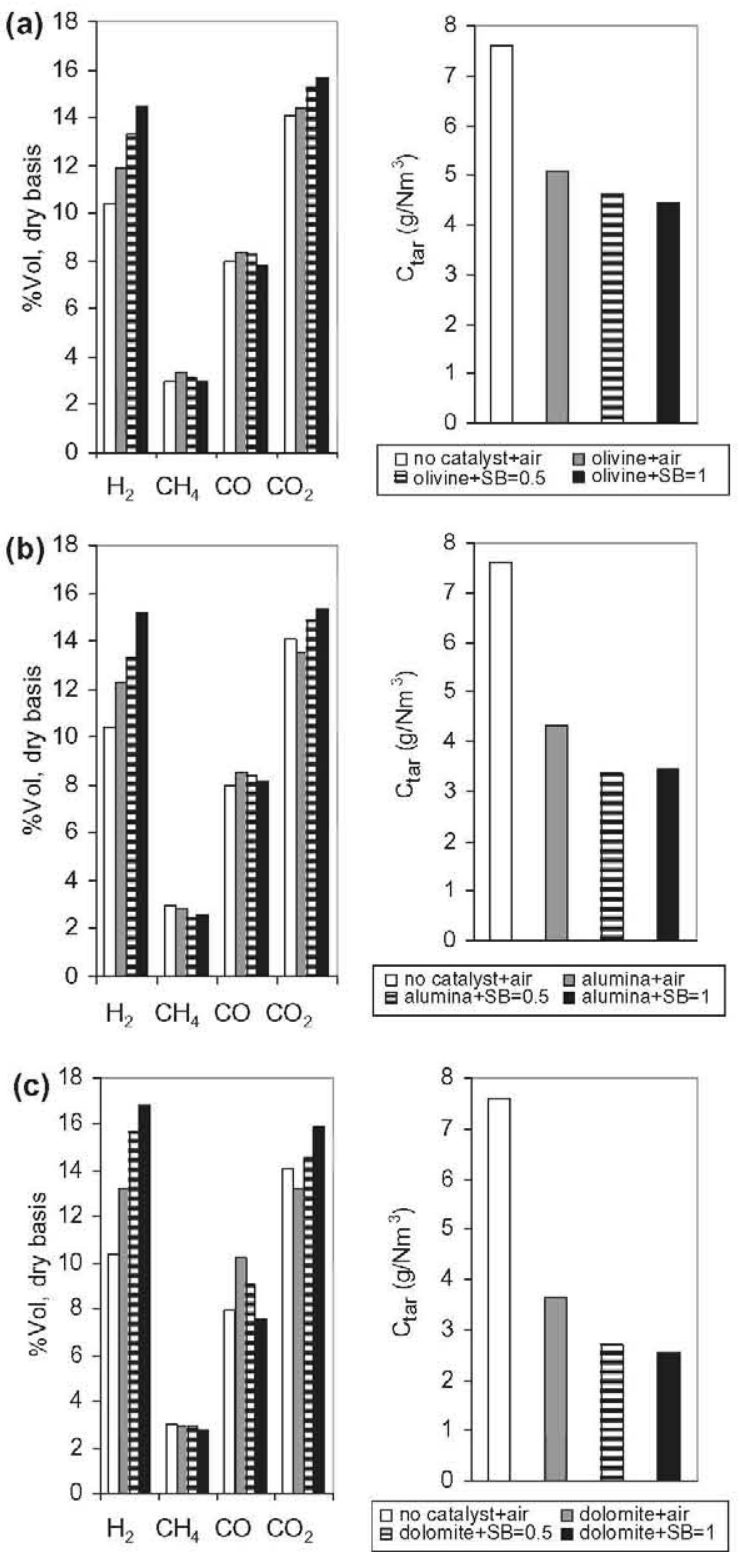

Fig. 6. Combined influence of steam and catalyst ( $10 \%$ catalyst, $E R=0.3, T=800^{\circ} \mathrm{C}$ ) on gas composition and tar concentration: (a) olivine; (b) alumina; (c) dolomite.

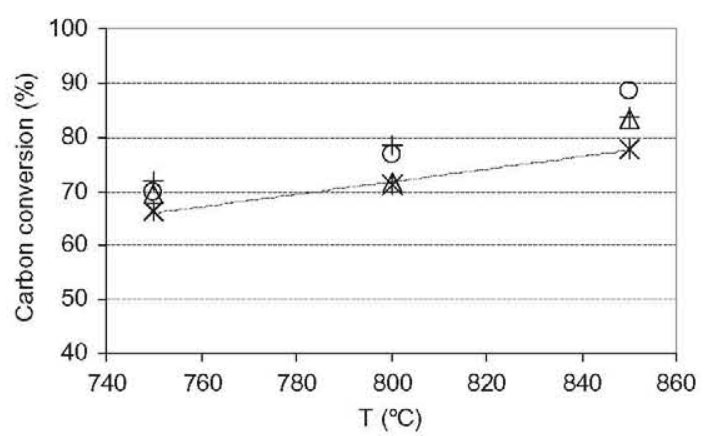

Fig. 5. Cold gas efficiencies and carbon conversions for different temperatures and catalysts in the bed ( $*$ no catalyst; $+15 \%$ olivine; $\Delta 15 \%$ alumina; $\bigcirc 15 \%$ dolomite). $\mathrm{ER}=0.3$. 

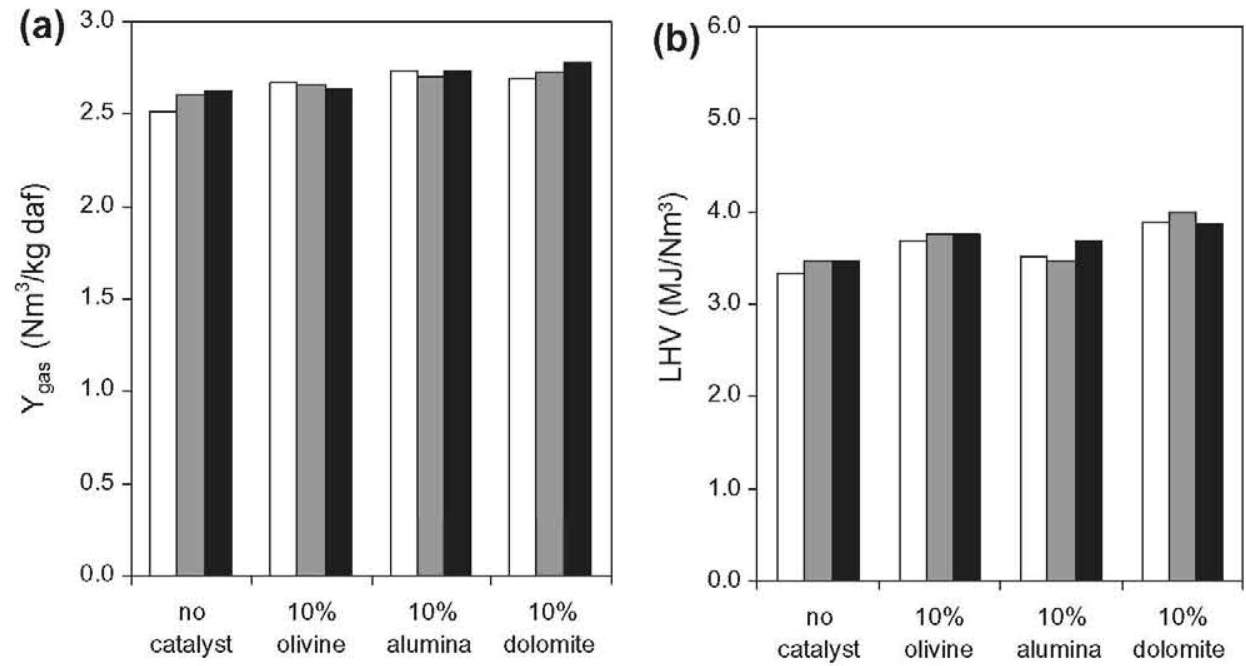

Fig. 7. Comparison of gas production and low heating values for different $\mathrm{SB}$ ratios $(\square 0 ; \square 0.5 ; \mathbf{\square}) . T=800^{\circ} \mathrm{C}, \mathrm{ER}=0.3$.

As can be seen in Fig. 5, the cold gas efficiency and the carbon conversion (calculated as described in [36]) were higher in the presence of catalysts due to the slight increase in gas production and the value of its LHV. The increase in gas production is associated with the conversion of tars into permanent gases, such as $\mathrm{H}_{2}, \mathrm{CO}, \mathrm{CO}_{2}$ and $\mathrm{CH}_{4}$. The increase of the LHV is caused because the decrease in $\mathrm{CH}_{4}$ content is compensated by the increase in $\mathrm{H}_{2}$ and $\mathrm{CO}$ contents. These latter increases were observed specially when alumina and dolomite were used (Fig. 3).

On average, when comparing these tests to the tests without catalysts, the cold gas efficiency was $9 \%$ higher with olivine, $10 \%$ higher with alumina and $19 \%$ higher with dolomite. Regarding carbon conversion, the improvement found with the use of catalysts was $9 \%$ for olivine, $5 \%$ for alumina and $10 \%$ for dolomite.

\subsection{Influence of catalysts and steam}

The results of the gasification tests carried out with catalysts and steam are shown in Table 2 (tests 16-19). Fig. 6 shows the variation in the gas composition and tar concentration found when using different catalysts and SB ratios with ER of 0.3 and a temperature of $800^{\circ} \mathrm{C}$. The results of the steam-catalysed assays were compared with those in which neither catalysts nor steam were used as presented in [33].

As can be seen in Fig. $6, \mathrm{H}_{2}$ and $\mathrm{CO}_{2}$ production increases in the presence of the steam-catalyst as compared with the tests in air without catalyst. In the case of $\mathrm{H}_{2}$, that increase is due to steamcarbon gasification reaction with subsequent changes in the gas phase caused by the reforming and water-gas shift reactions. These trends, together with the decrease in CO content for increasing $\mathrm{SB}$, are in agreement with $[22,26,27]$.

When alumina and dolomite are used hydrogen contents of $15 \%$ and $17 \%$ by volume at $800^{\circ} \mathrm{C}$ are achieved, respectively. The $\mathrm{CH}_{4}$ and $\mathrm{C}_{n} \mathrm{H}_{m}$ production decreases mainly due to steam and $\mathrm{CO}_{2}$ reforming reactions. Additional reductions of these gases are found by increasing the amount of water added to the gasifier (Table 2 ).

An advantage of the use of steam and catalysts together is the associated increase in the $\mathrm{H}_{2} / \mathrm{CO}$ ratio. This ratio rose from 1.3 (in the tests with air and without catalysts) to 1.8 in the tests with steam-olivine and steam-alumina. The ratio reached 2.2 in the tests with steam-dolomite.

Fig. 6 shows how the production of tars decreases in the presence of catalysts and steam. The reductions in tar contents were $13 \%, 20 \%$ and $30 \%$ as compared to the tests with air-catalyst and
$42 \%, 55 \%$ and $66 \%$ as compared to the tests in air without catalyst for olivine, alumina and dolomite, respectively.

As can be seen in Fig. 7, the addition of steam to the catalysed gasification process does not have a significant effect on gas production. The slight increase detected is due to reforming reactions and, probably, to water-gas reaction involving char and steam the latter not only by producing permanent gases but leading to the observed decrease in char production (Table 2). A similar trend is found with the LHV; although the combination of a catalyst and steam led to increases in $\mathrm{H}_{2}$, the reduction in $\mathrm{CO}$ and $\mathrm{CH}_{4}$ content due to the water-gas shift and steam reforming reactions kept the LHV almost constant.

As a result of the small variations found in the gas production and the LHV, cold gas efficiencies and carbon conversions are slightly higher when steam is added to the process. With respect to tests with catalysts and without steam, the cold gas efficiency increased on average by $1 \%$ with olivine, $7 \%$ with alumina and $4 \%$ with dolomite. Regarding carbon conversion, averaged growths of $1 \%$ with olivine, $9 \%$ with alumina and $2 \%$ with dolomite were found.

\section{Conclusions}

This paper deals with the influence of different primary catalysts - olivine, alumina and dolomite - on the products of sewage sludge gasification with air and air-steam mixtures. The comparison of the catalysts' performances is focused on the gas composition and tar production as well as the production and LHV of the gases, the cold gas efficiency and the carbon conversion.

Tar production is significantly reduced in the presence of catalysts. Dolomite is the most active, and olivine is the least effective. Regarding the gas composition, alumina and dolomite increases the production of $\mathrm{H}_{2}$ and $\mathrm{CO}$ and decreases the production of $\mathrm{CH}_{4}, \mathrm{CO}_{2}$ and $\mathrm{C}_{n} \mathrm{H}_{m}$ due to cracking reactions and steam and $\mathrm{CO}_{2}$ reforming reactions. Olivine has a slight effect on the gas composition. Gas production and LHV increases in the presence of catalysts, leading to the improvements in the cold gas efficiency and carbon conversion.

The combined use of a catalyst and steam results in increases in $\mathrm{H}_{2}$ and $\mathrm{CO}_{2}$ and decreases in the $\mathrm{CH}_{4}, \mathrm{CO}$ and $\mathrm{C}_{n} \mathrm{H}_{m}$ contents of the gases. These trends are caused by the greater importance of the water-gas shift reaction and by the effect of the reforming reactions. Additional tar elimination is found when steam is used in 
the presence of a catalyst but, in these catalysed tests, steam improves the quality of the gas (higher hydrogen production and lower tar content) but has no significant influence on the cold gas efficiency or the carbon conversion.

During the tests carried out in this work a high resistance to attrition was found for olivine and alumina. In the case of dolomite, an important carryover of solids from the gasifier was detected. In future works, it would be interesting to conduct a set of tests to quantify the actual carryover of different catalysts under typical gasification conditions.

\section{Acknowledgements}

This work was partly financed by the Canal de Isabel II. Juan Manuel de Andrés Almeida would like to thank the Universidad Politécnica de Madrid (Technical University of Madrid) for a doctoral grant.

\section{References}

[1] Dogru M, Midilli A, Howarth CR. Gasification of sewage sludge using a throated downdraft gasifier and uncertainty analysis. Fuel Process Technol 2002;75:55-82.

[2] Urban Waste Water Treatment Directive (UWWTD) (91/271/EEC), amended by Directive 98/15/EC.

[3] Sewage Sludge Directive 86/278/EEC.

[4] Council Directive 99/31/CE, 26 April 1999, on the landfill of waste.

[5] Adegoroye A, Paterson N, Li X, Morgan T, Herod AA, Dugwell DR, et al. The characterisation of tars produced during the gasification of sewage sludge in a spouted bed reactor. Fuel 2004;83:1949-60.

[6] Manyà JJ, Sánchez JL, Âbrego J, Gonzalo A, Arauzo J. Influence of gas residence time and air ratio on the air gasification of dried sewage sludge in a bubbling fluidised bed. Fuel 2006;85:2027-33.

[7] Fytili D, Zabaniotou A. Utilization of sewage sludge in EU application of old and new methods - a review. Renew Sustain Energy Rev 2008;12:116-40.

[8] Ciferno JP, Marano JJ. Benchmarking biomass gasification technologies for fuels, chemicals and hydrogen production. US Department of Energy. National Energy Technology Laboratory; 2002.

[9] Campoy M, Gómez-Barea A, Villanueva A, Ollero P. Air-steam gasification of biomass in a fluidized bed under simulated autothermal and adiabatic conditions. Ind Eng Chem Res 2008;47:5957-65.

[10] Elías X. Tratamiento y valorización energética de residuos. ed Díaz de Santos; 2005.

[11] Narváez I, Corella J, Orio A. Fresh tar (from a biomass gasifier) elimination over a commercial steam reforming catalyst. Kinetics and effect of different variables of operation. Ind Eng Chem Res 1997;36:317-27.

[12] Manyà JJ, Sánchez JL, Gonzalo A, Arauzo J. Air gasification of dried sewage sludge in a fluidized bed: effect of the operating conditions and in-bed use of alumina. Energy Fuels 2005;19:629-36.

[13] Simell P, Bredenberg JB. Catalytic purification of tarry fuel gas. Fuel 1990;69: 1219-25.

[14] Devi L, Ptasinski Krzysztof J, Janssen Frans JJG, van Paasen Sander VB, Bergman Patrick CA, Kiel Jacob HA. Catalytic decomposition of biomass tars: use of dolomite and untreated olivine. Renew Energy 2005;30:565-87.

[15] Azhar Uddin Md, Tsuda H, Wu S, Sasaoka E. Catalytic decomposition of biomass tars with iron oxide catalysts. Fuel 2008;87:451-9.

[16] Han J, Kim H. The reduction and control technology of tar during biomass gasification/pyrolysis: an overview. Renew Sustain Energy Rev 2008;12: 397-416.

[17] Bridgwater AV. The technical and economic feasibility of biomass gasification for power generation. Fuel 1995;74:631-53.

[18] Milne TA, Evans RJ. Biomass gasifier "tars": their nature, formation and conversion. National Renewable Energy Laboratory, NREL/TP-570-25357; 1998.

[19] Delgado J, Aznar MP, Corella J. Calcined dolomite magnesite and calcite for cleaning hot gas from a fluidized bed biomass gasifier with steam: life and usefulness. Ind Eng Chem Res 1996;35:3637-43.
[20] Orío A, Corella J, Narváez I. Performance of different dolomites on hot raw gas clearing from biomass gasification with air. Ind Eng Chem Res 1997;36: 3800-8.

[21] $\mathrm{Hu} \mathrm{G}, \mathrm{Xu} \mathrm{S}$, Li S, Xiao Ch, Liu S. Steam gasification of apricot stones with olivine and dolomite as downstream catalysts. Fuel Process Technol 2006;87:375-82

[22] Lv PM, Yuan Z, Wu Ch, Ma L, Chen Y, Tsubaki N. Bio-syngas production from biomass catalytic gasification. Energy Convers Manage 2007;48:1132-9.

[23] Devi L, Ptasinski Krzysztof J, Janssen Frans JJG. A review of the primary measures for tar elimination in biomass gasification processes. Biomass Bioenergy 2003;24:125-40.

[24] Corella J, Aznar MP, Gil J, Caballero MA. Biomass gasification in fluidized bed: where to locate the dolomite to improve gasification? Energy Fuels 1999;13: $1122-7$.

[25] Olivares A, Aznar MP, Caballero MA, Gil J, Francés E, Corella J. Biomass gasification: produced gas upgrading by in-bed use of dolomite. Ind Eng Chem Res 1997;36:5220-6.

[26] Gil J, Caballero MA, Martín JA, Aznar MP, Corella J. Biomass gasification with air in a fluidized bed: effect of the in-bed use of dolomite under different operation conditions. Ind Eng Chem Res 1999;38:4226-35.

[27] Rapagná S, Jand N, Kiennemann A, Foscolo PU. Steam-gasification of biomass in a fluidised-bed of olivine particles. Biomass Bioenergy 2000;19:187-97.

[28] Corella J, Toledo JM, Padilla R. Olivine or dolomite as in bed additive in biomass gasification with air in a fluidized bed: which is better? Energy Fuels 2004:18:713-20.

[29] Miccio F, Piriou B, Ruoppolo G, Chirone R. Biomass gasification in a catalytic fluidized reactor with beds of different materials. Chem Eng J 2009:154:369-74

[30] Czernik S, French R, Feik C, Chornet E. Hydrogen by catalytic steam reforming of liquid byproducts from biomass thermoconversion processes. Ind Eng Chem Res 2002;41:4209-15.

[31] Magrini-Bair KA Czernik S, French R, Parent YO, Chornet E, Dayton DC, et al. Fluidizable reforming catalyst development for conditioning biomass-derived syngas. Appl Catal A: Gen 2007;318:199-206.

[32] CEN/TS 15439:2006: Biomass gasification, tar and particles in product gases, sampling and analysis. CEN Technical Specification.

[33] de Andrés JM, Narros A, Rodríguez ME. Air-steam gasification of sewage sludge in a bubbling bed reactor: effect of alumina as primary catalyst. Fuel Process Technol. Unpublished results.

[34] Aznar M, González AE, Manyá JJ, Sânchez JL, Murillo MB. Understanding the effect of the transition period during the air gasification of dried sewage sludge in a fluidized bed reactor. Int J Chem Reactor Eng 2007;5:art. A18.

[35] Skoulou V, Koufodimos G, Samaras Z, Zabaniotou A. Low temperature gasification of olive kernels in a $5-\mathrm{kW}$ fluidized bed reactor for $\mathrm{H}_{2}$-rich producer gas. Int J Hydrogen Energy 2008;33:6515-24.

[36] Cao Y, Wang Y, Riley JT, Pan W-P. A novel biomass air gasification process for producing tar-free higher heating value fuel gas. Fuel Process Technol $2006 ; 87: 343-53$

\section{Glossary}

daf: dry and ash-free

$E R$ : equivalence ratio, defined as the ratio between the flow rate of the air introduced into the reactor and the stoichiometric flow rate of the air required for complete combustion of the sludge, \%

$L H V$ : low heating value of the produced gas, $\mathrm{MJ} / \mathrm{Nm}^{3}$, dry basis

$S B$ : steam-to-biomass ratio, defined as the flow rate of steam fed to the reactor divided by the flow rate of sludge, daf

$X_{\mathrm{H}_{2} \mathrm{O}}$ : water conversion in the gasifier, \%

$u$ : superficial gas velocity in the gasifier bed, $\mathrm{cm} / \mathrm{s}$

$u_{\mathrm{mf}}$ : minimum fluidisation gas velocity (gasifier bed conditions) $\mathrm{cm} / \mathrm{s}$

$\mathrm{Nm}^{3}$ : cubic meter, normal conditions $\left(0^{\circ} \mathrm{C}, 101 \mathrm{kPa}\right)$

$Y_{\text {gas: }}$ : gas yield, $\mathrm{Nm}^{3}$ dry gas $/ \mathrm{kg}$ sludge, daf

$C_{\text {tar: }}$ tar concentration, $\mathrm{g} / \mathrm{Nm}^{3}$

$Y_{\text {tar: }}$ : tar yield, $\mathrm{mg} / \mathrm{g}$ sludge, daf

GMB: global mass balance, \%

$X_{c}$ : carbon conversion, weight of carbon in the produced gas divided by weight of carbon in the sludge introduced in the gasifier

GE (cold gas efficiency): LHV of gas divided by the LHV of sludge 